\title{
Deciphering the Biocontrol Potential of Streptomyces sp. in Plant Disease Management: A Review
}

\author{
Johnson, I. ${ }^{1 *}$, Kavitha, R. ${ }^{1}$, Karthikeyan, M. ${ }^{1}$, Ramjegathesh, R. ${ }^{3}$ and Anandham, R. ${ }^{2}$
}

${ }^{1}$ Department of Plant Pathology, TNAU, Coimbatore, Tamil Nadu, India

${ }^{2}$ Department of Agricultural Microbiology, TNAU, Coimbatore, Tamil Nadu, India

${ }^{3}$ Rice Research Station, Ambasamudram, Tamil Nadu, India

*Corresponding author: johnsonpath@gmail.com (ORCID ID: 0000-0003-1631-9246)

Paper No. 943

Received: $17-09-2021$

Revised: 25-11-2021

Accepted: 06-12-2021

\begin{abstract}
Crop losses in agriculture are getting aggravated due to several abiotic and biotic factors including diseases caused by fungi, bacteria and viruses. Chemical fertilizers are applied to overcome which it is not a feasible method. Hence an alternative method should be found, to sought out the problems of using chemicals. Plant disease management using microbes is gaining interest recent days for replacing the chemicals. Among all, Streptomyces a gram-positive saprophytic bacterium stages a substantial role in combating plant diseases owing to its capability to induce or synthesis bioactive rich antimicrobial metabolites and enzymes. It is presumed that they are distributed wide in nature, but the rhizosphere region constitutes the most potential antibiotic producing organisms and are used as bio inoculant. Besides, it also increases the plant growth by producing plant growth promoting substances and suppress the disease through mechanism like antibiosis, mycoparasitism and nutrient competition; supplying of nutritive elements like iron, copper, phosphorus and sulphur; synthesis of plant hormones like IAA, cytokinin and siderophore. This review briefly illustrates about the role, mechanism, advantage and disadvantage of using Streptomyces spp. in plant disease management.

\section{HIGHLIGHTS}

( Actinobacteria are known antibiotic producers.

(0 They were effective against plant pathogens through various modes of action like mycoparasitism, competition, analysis and also through induction of defense proteins.

(0 Besides, they influence plant growth through production of growth hormones also.

(- A collective documentation about the role of actinobacteria in plant growth and disease management is the need of researchers.
\end{abstract}

Keywords: Streptomyces, biocontrol, antibiosis, antimicrobial compound

The increasing demands on food production led to the dependence on chemical fertilizers and pesticides for increasing the productivity (Bhardwaj et al. 2014) and the decrease in productivity may be attributed to many reasons. Among all, pests and pathogens tops the list and the pathogen infection ranges between 20 to $40 \%$ (Savary et al. 2012). The extensive use of chemicals compounds lead to deposition of detrimental residues, development of fungicide resistance in plants, detrimental to non-targeted and beneficial microorganisms
(Bharathi et al. 2004). Alternative measures like genetic engineering of plants for disease resistance, high yielding varieties are time consuming and demands strategies which can evade limitations of agricultural production (Rey and Dumas 2017). Hence, an emphasis on using microbes appears

How to cite this article: Johnson, I., Kavitha, R., Karthikeyan, M., Ramjegathesh, R. and Anandham, R. 2021. Deciphering the Biocontrol Potential of Streptomyces sp. in Plant Disease Management: A Review. Int. J. Ag. Env. Biotech., 14(04): 547-559.

Source of Support: None; Conflict of Interest: None 
to be a sustainable solution for increasing the crop yield. Plant disease management through microbes plays a significant role because of its environment friendliness. Plant beneficial microbes are copious in the rhizosphere region which are used as bio inoculants and which has the capacity to maintain the soil environment by fixing the nitrogen, solubilizing the nutrients like phosphate and potassium, liberating plant growth stimulating constituents, synthesis of antibiotic compounds, and improvement of soil organic matter content through biodegradation processes (Bhardwaj et al. 2014).

Among all microbes, actinomycetes receives wide attention because of its potential antibiotic production which are used for controlling various plant pathogens. Mechanism employed by them includes mycoparasitism, competition for nutrients, production of hydrolytic enzymes and antimicrobial metabolites and regulation of plant defense. As per Bergey's Manual of Systematic Bacteriology (Whitman et al. 2012), actinomycetes renamed as actinobacteria of which Streptomyces is widely studied since it can be grown in laboratory on artificial media. About $10 \%$ of soil microflora is contributed by Streptomyces sp. having antifungal, antibacterial, antiviral and antioxidant activities. 60 $\%$ of the antibiotic production is by Streptomyces, besides producing hormones like IAA and siderophore responsible for improvement of plant growth. In a nutshell, use of actinomycetes possessing antimicrobial activity might be an alternative for chemical fertilizers in plant disease management owing to its low cost of production, environment safety and reduction in usage of natural non-replenishable resources. Keeping in view the importance and potentiality, application of Streptomyces sp. as a bio inoculant and its mechanisms are reviewed here.

\section{Actinobacteria}

Actinobacteria sharing the characteristics of fungi and bacteria, are pervasive in soil, compost, atmosphere and fresh water basins in different depths globally. They belong to the Bacterial kingdom, under Actinobacteria phylum, in the Actinomycetes class, and actinomycetales order, with Actinomycetaceae family, a bacterium with high genomic $\mathrm{G}+\mathrm{C}$ content $(74 \mathrm{~mol} \%)$ and grampositive in nature (Elamvazhuthi and Subramanian,
2013). Malviya et al. 2009 and Gopalakrishnan et al. 2011 had isolated many such isolates from plant rhizosphere and among them Streptomyces spp. was extensively explored for their potential antimicrobial activity. Waksman and Henrici in 1943 familiarized Streptomyces for the first time (Goodfellow and Williams et al. 1983), as the type genus of the family Streptomycetaceae, distinguished by physiological and morphological characteristics, type of fatty acids chains, phospholipids, peptidoglycan, GC content (\%), chemical constituents of cell walls, $16 \mathrm{~S}$ rRNA analysis and DNA hybridization (Bhardwaj et al. 2014).

Actinobacteria produces an array of secondary metabolites with high commercial interest, among which genus Streptomyces tops in the production with discovery of actinomycin. Functions employed includes the degradation of organic substrates like proteins, fats, cellulose, humus and produce the characteristic earthy smell of soil due to geosmin content (Anandan et al. 2016).

Streptomyces is a major genus representing over 500 species, chemoorganotrophic, filamentous Gram +ve and not acid-fast organism. Majority of the species are mesophile $\left(10-37^{\circ} \mathrm{C}\right)$ while some are thermophile $\left(45-55^{\circ} \mathrm{C}\right)$ with $\mathrm{pH}$ of $6.5-8.0$ (e.g) Streptomyces thermoflavus, S. thermonitrificans and S. thermovulgaris (Gowdar et al. 2018). They are sensitive to water logged conditions, form arthrospores and are more resistant to drought. Few reports illustrated that sandy loam and calcareous soil possess more Streptomyces than heavy clay soil. Production of substrate and aerial mycelium occurs in which substrate hyphae are $0.5-0.1 \mu \mathrm{m}$ dia. As it ages, production of aerial mycelium begins resulting in formation of chain of spores (conidia) (Wildermuth 1970; Wildermuth and Hopwood 1970). The spores are formed by fragmentation and are arranged in helical, wavy or strait chains. The colonies are growing slow with initial smooth edges and progress in to crosswise mycelial threads later which appear velvety, powdery, floccose or granular with the typical earthy odour.

\section{Isolation and characterization}

Geographical factors like soil type, $\mathrm{pH}$, temperature, organic content, farming, soil moisture and aeration determines the type and number of actinomycetes present. The actinomycetes could be isolated using 
several media viz., Kenknight's agar medium, Starch casein agar medium, Actinomycetes Isolation Agar and Yeast extract-malt extract agar etc. Adegboye et al. (2012) isolated several strains from rhizosphere soil of cabbage spinach, sunflower, maize and onion on starch casein agar medium with $10 \mu \mathrm{g} / \mathrm{ml}$ cycloheximide as and $25 \mu \mathrm{g} / \mathrm{ml}$ streptomycin as supplements to prevent the contamination by other bacteria and fungi. Similarly, from wheat and tomato rhizosphere soil, 98 plant growth promoting actinomycetes were isolated using the ISP 4 (Inorganic salt starch agar) medium (Anwar et al. 2016).

Actinomycetes had soil-like odour, pastel colours and stick into the agar (Kalyani et al. 2012). While growing on agar surface, the isolates produced a network of branching hyphae on both sides of agar (i.e.,) aerial mycelium on upper surface and substrate mycelium on lower surface (Sharma et al. 2014). The colonies are often leathery, compact with dry appearance on media covered with substrate and aerial mycelium of different colony colour, shape (Fig. 1).

Classical approaches for identifying actinomycetes includes physiological, morphological and biochemical methods based on Bergey's Manual of Determinative Bacteriology. Morphology of spore chain was classified into retinaculiaperti (RA), rectiflexibiles $(\mathrm{RF})$, and spirales (S) (Madigan et al. 2012) (Fig. 2.).
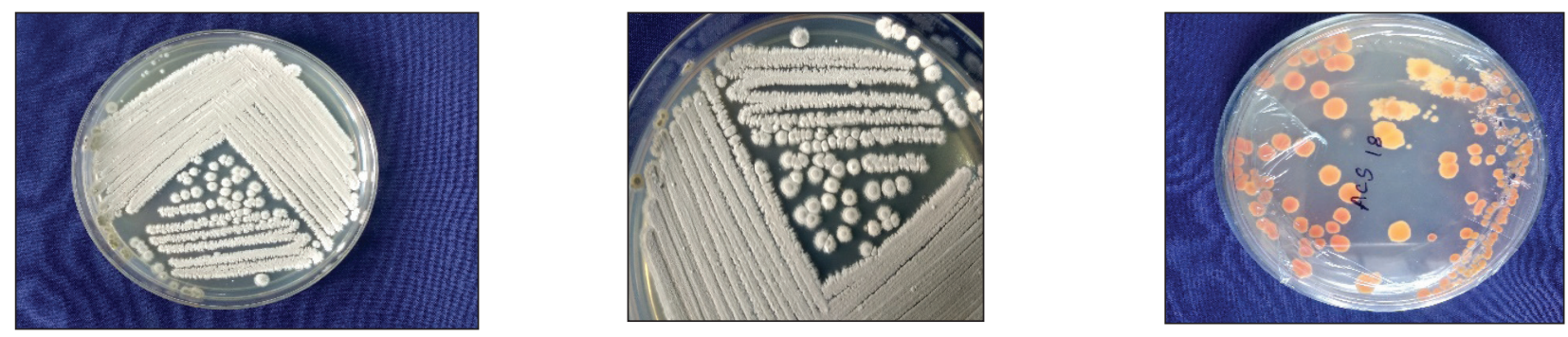

Fig. 1: Growth of Streptomyces isolates on Starch casein agar medium; (a) aerial mycelium; (b) individual colony morphology; (c) substrate mycelium

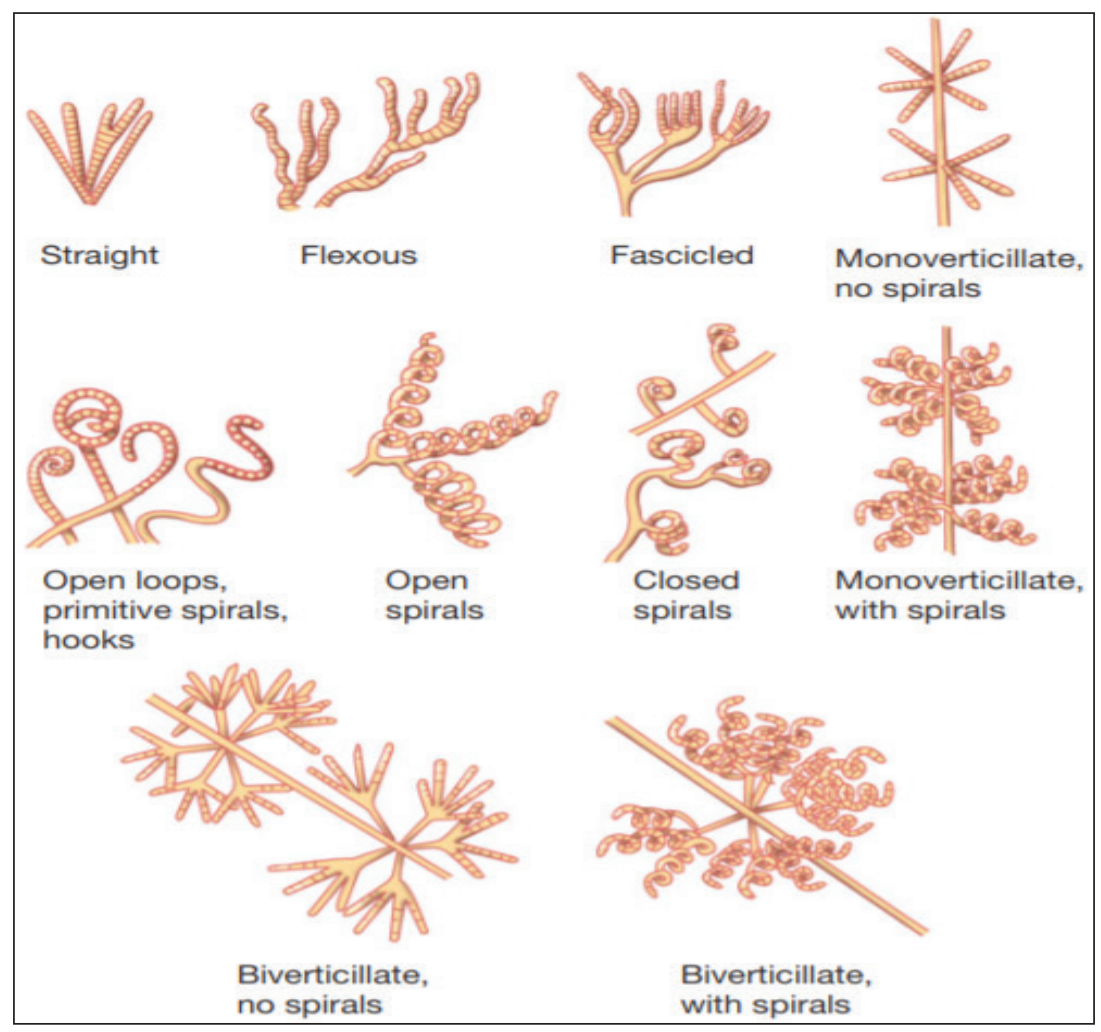

Fig. 2: Structure of spores produced by Streptomyces species (Madigan et al. 2012) 
Physiological method of identification includes optimizing the range of temperature, $\mathrm{pH}$ and different concentrations of sodium chloride for growth of organism. Biochemical tests include nitrate reduction catalase production, hydrogen sulphide production, starch hydrolysis, gelatin liquefaction, Vogues-Proskauer test urease production, indole production, citrate utilization test and methyl red test (Sharma et al. 2014) while, molecular characterization is been done using the 16S rRNA universal primer 27F (5'-AGAGTTTGATCCTGGCTCA-3') and 1492R (5'ACGGCTACCTTGTTACGACT-3') and genus specific primer like Sm6F GGTGGCGAAGGCGGA, Sm5R GAACTGAGACCGGCTTTTTGA (Masand et al. 2018).

\section{Streptomyces as a bio inoculant}

Streptomyces spp. has the capacity of decomposing biopolymers like lignocellulose, starch, chitin in soil and water and organic matter. Streptomyces as bioactive compound became evident after the discovery of streptomycin which paved a way forward for detection of antimicrobial compounds. Malviya et al. 2009 and Gopalakrishnan et al. 2013 had isolated many number of actinomycetes from rhizosphere soil collected from various locations and screened for its novel microbial compounds. Among the actinobacteria, Streptomyces sp. alone contributed for $75 \%$ of antibiotic production used as agrochemicals and in pharmaceuticals (Berdy 2005). They have also gained importance in plant disease management through production of extracellular hydrolytic enzymes (Prapagdee et al. 2008; Joo, 2005; Elamvazhuthi and Subramanian 2013 and Gopalakrishnan et al. 2013). Formation of thread like filaments in soil is advantageous for colonizing the rhizosphere efficiently. Besides, they promote the plant growth, make nutrients available and antagonize with pathogens. They are exploited in production of antibiotics, bactericides, insecticides, fungicides, acaricides, and herbicides and applied as spore suspension, culture filtrate, wettable granules, wettable powder and emulsifiable concentrates.

\section{Mechanism employed by Streptomyces against plant pathogens}

Streptomyces species are capable of suppressing pathogen by performing functions as a source for bioactive compounds, extracellular enzymes and antibiotics (Fig. 3).

\section{(i) Mycoparasitism / hydrolytic enzymes}

In biocontrol of plant diseases, enzymes play a significant role like parasitism and antibiosis. Cell wall degrading enzymes like $\beta$-1,3-glucanase, chitinase, cellulase and protease are essential

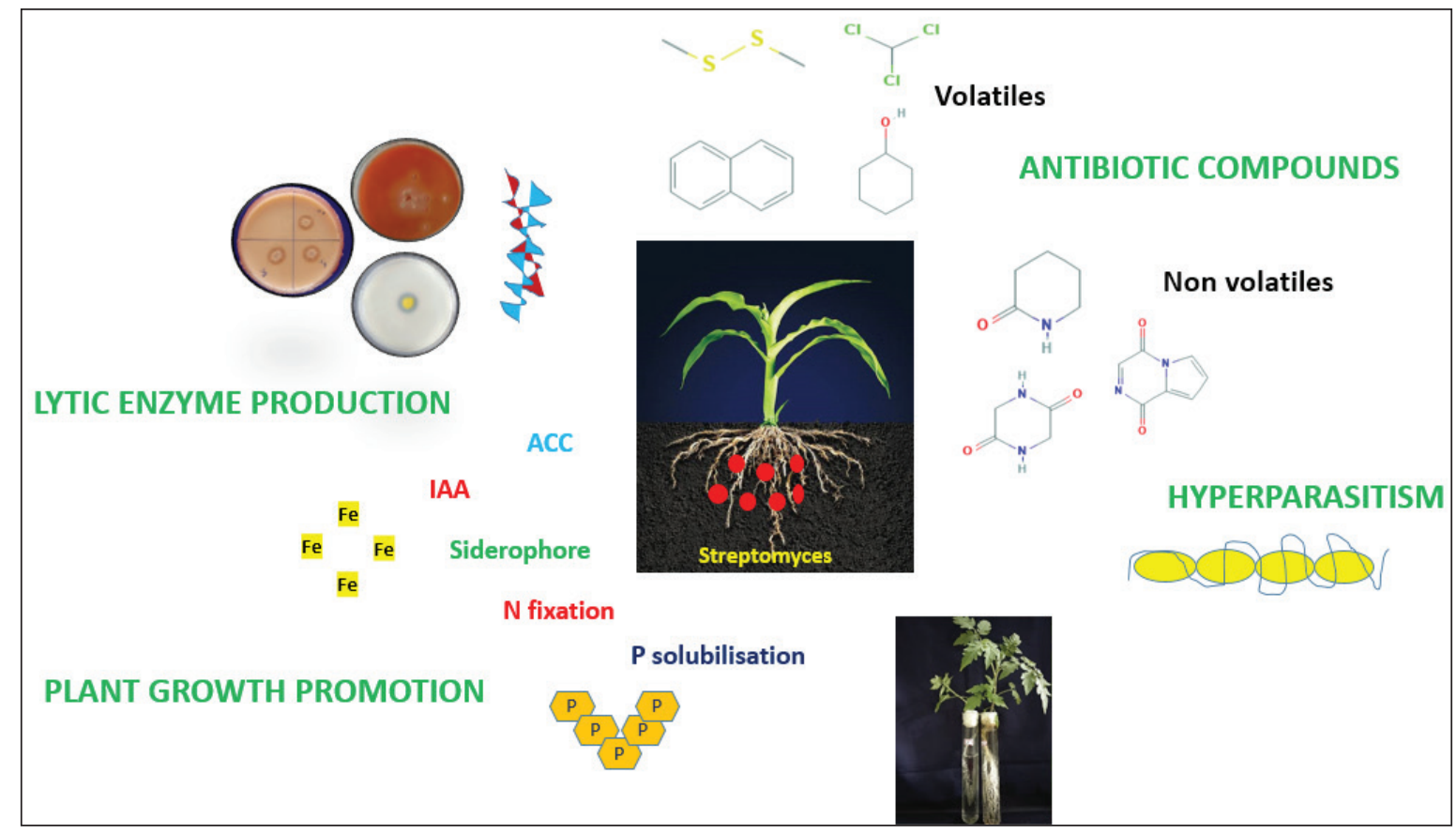

Fig. 3: Mode of action of Streptomyces against plant pathogens 
Table 1: List of Streptomyces species used against different plant pathogens

\begin{tabular}{|c|c|c|c|}
\hline Streptomyces & Disease & Pathogen & Reference \\
\hline Streptomyces sp. S30 & Tomato Damping-off & Rhizoctonia solani & Cao et al. (2004) \\
\hline Streptomyces spp. 47W08, 47W10 & Pepper Blight & Phytophthora capsici & Liang et al. (2005) \\
\hline S. cavurensis NRRL 2740 & & Colletotrichum gloeosporioides & Intra et al. (2011) \\
\hline S. toxytricini vh6 & Tomato Root rot & R. solani & Patil et al. (2011) \\
\hline $\begin{array}{l}\text { Streptomyces (CAI-24, CAI-121, } \\
\text { CAI-127, KAI-32 and KAI90) }\end{array}$ & Chickpea Fusarium wilt & Fusarium spp. & $\begin{array}{l}\text { Gopalkrishnan et al. } \\
(2013)\end{array}$ \\
\hline S. griseoviridis & Cucumber Damping-off & Pythium spp. & Junaid et al. (2013) \\
\hline S. rochei ACTA 1551 & Tomato Fusarium wilt & $\begin{array}{l}\text { Fusarium oxysporum f.sp. } \\
\text { lycopersici }\end{array}$ & Kanini et al. (2013) \\
\hline Streptomyces sp. CBE & Groundnut Stem rot & Sclerotium rolfsii & $\begin{array}{l}\text { Adhilakshmi et al. } \\
(2014)\end{array}$ \\
\hline Streptomyces spp. & Tomato Damping-off & R. solani & Goudjal et al. (2014) \\
\hline S. aurantiogriseus VSMGT1014 & Rice Sheath blight & R. solani & $\begin{array}{l}\text { Harikrishnan et al. } \\
(2014)\end{array}$ \\
\hline S. misionensis NBRC & Rice Brown spot, Sheath blight & $\begin{array}{l}\text { Helminthosporium oryzae, } R \text {. } \\
\text { solani }\end{array}$ & $\begin{array}{l}\text { Poomthongdee et al. } \\
(2015)\end{array}$ \\
\hline $\begin{array}{l}\text { Streptomyces strain PC 12, } \\
\text { Streptomyces strain D 4.1, } \\
\text { Streptomyces strain D } 4.3 \text { and } \\
\text { Streptomyces strain W1 }\end{array}$ & Rice & Pyricularia sp. & Chaiharn et al. (2020) \\
\hline
\end{tabular}

for antifungal activities (Haggag and Mohamed 2007). Actinobacteria are potential producers of $\beta$-1, 3-glucanase, chitinase, amylase, pectinase, cellulase, xylanase, lipase and protease and are specifically produced from actinomycetes isolated from agricultural soil (Sonia et al. 2011). Glucanase and chitinase were leading to complete dissolution of Sclerotium rolfsii, Sclerotinia minor, Aspergillus and Fusarium oxysporum (Hassan et al. 2011). Two hundred and eighty-three chitinolytic actinomycetes were isolated from rhizosphere soils of Sisaket Province and Ubon Ratchathani, Thailand was isolated by Pattanapipitpaisal and Kamlandharn
(2012), among which 13 isolates showed potentiality for inhibiting the fungal growth emphasizing its usage as biocontrol agent. Srividya et al. (2012) reported $\beta-1,3$ and $\beta-1,4$ glucanase, chitinase, protease and lipase producing isolates from Solanaceae rhizosphere having possible role against fungal pathogens like Alternaria alternata, A. brassicola, A. brassicaceae, Rhizoctonia solani, Colletotrichum gloeosporioides, and Phytophthora capsici.

The second most abundant organic compound in the cell wall next to cellulose is chitin and the 
chitinase enzyme produced by Streptomyces spp. has the capacity to depolymerize it. Hence it could be exploited as a promising tool in biocontrol either directly or indirectly by usage of purified proteins (Sonia et al. 2011). Chitinase producing isolates from chilli rhizosphere exhibited antimicrobial potential against Colletotrichum capsici and Fusarium oxysporum (Ashokvardhan et al. 2014). S. griseoloalbus from cucumber rhizosphere suppressed the damping-off pathogen Pythium aphanidermatum when compared with metalaxyl by producing cell wall degrading enzymes (El-Tarabily and Sivasithamparam 2006). The conidial germination of cucumber wilt pathogen F. oxysporum f. sp. cucumerinum was inhibited by the actinobacteria S. bikiniensis strain HD-087 which triggered defense related enzyme $\beta-1,3$ glucanase, phenylalanine ammonialyase and peroxidase against the pathogen (Zhao et al. 2012).

\section{(ii) Antibiosis}

Actinobacteria have the capability to produce many volatiles, toxins and antibiotics. Among actinomycetes Streptomyces are potential producer of several secondary metabolites having capability to act as fungicides against the plant diseases besides ensuring environmental safety (Siupka et al. 2021). S. padanus Strain JAU4234 which produced fungichromin, actinomycin X2 and antifungalmycin 702 and showed antifungal activity by changing the structure of cell membranes and the cytoskeleton in Rhizoctonia solani in addition to interaction with the cellular organelles (Xiong et al. 2013). Similarly, S. olivaceiscleroticus AZ-SH514 and S. antibioticus AZ-Z710 were known to produce mycangimycin and 4 phenyl-1-napthyl-phenyl acetamide which were showing antibacterial activity against Staphylococcus aureus, Micrococcus lutea, Bacillus subtilis, B. pumilus, Klebsiella pneumonia, Escherichia coli, Pseudomonas aeruginosa, Saccharomyces cerevisiae, Candida albicans and antifungal activity against Aspergillus flavus, A. niger, A. fumigatus, Fusarium oxysporum, Rhizoctonia solani, Alternaria alternata, Botrytis fabae and Penicillium chrysogenium (Atta et al. 2015). Similarly, the antibiotic compounds geldanamycin, guanidylfungin $\mathrm{A}$ and nigericin produced by $S$. violaceusniger YCED9 were showing antifungal activity against Phytophthora, Pythium and Fusarium spp. besides producing the chitinases and $\beta$-1,3-glucanase enzymes (Trejo-Estrada et al. 1998).
Polyoxins B and D obtained from S. cacaoivar functions by inhibiting the chitin syntheses (Isono et al. 1965). Mildiomycin from Streptoverticillium rimofaciens inhibits protein biosynthesis in powdery mildew (Harada and Kishi 1978). Polyene from Streptomyces plumbeus effective against Botrytis cinerea (Kim et al. 2020), macrolide antibiotic oligomycin A from S. libani was active against pathogenic fungi Botrytis cinerea, Cladosporium cucumerinum, Colletotrichum lagenarium, Magnaporthe grisea and Phytophthora capsici (Kim et al. 2011), and isochainin from an S. marokkonensis AP1 strain inhibitory towards F. oxysporum f. sp. albedinis and V. dahliae (Bouizgarne, et al. 2009; Saxena 2014). Kasugamycin a bactericidal and fungicidal metabolite from Streptomyces kasugaensis effective against rice blast Pyricularia oryzae by inhibiting the protein biosynthesis in microorganisms (Law et al. 2017) and Pseudomonas diseases of several crops (Sharma et al. 2014). Cyclic lipopeptide daptomycin from S. roseosporus (Liu et al. 2018) geldanamycin, nigericin and Oligomycin A of $S$. diastatochromogenes exhibited inhibitory activity against many pathogenic fungi (Yang et al. 2010).

The antibiotics 2,5-Piperazinedione and Pyrrolo [1,2-a]pyrazine-1,4-dione, hexahydro functions by reducing or scavenging the volume of free radicles (Morales-González, 2013) exhibiting antioxidant activity. Propyl ester of octadecanoic acid produced by $S$. albolongus S9 was highly inhibitory to Corynespora cassiicola causing spot disease in tomato (Devi and Rao 2017).

Volatile organic compounds are diffusible and low molecular weight compounds and produced by many Streptomyces spp. exhibit strong antifungal activity. The compounds produced belonged to aldehydes alkanes, aromatic hydrocarbons, alcohols, alkenes, ketones, furans, esters, and ethers. Volatiles from $S$. platensis strain F-1, established resistance against Rhizoctonia solani on rice, Sclerotinia sclerotiorum on oilseed rape and Botrytis cinerea on strawberries (Wan et al. 2008). Phenol,2-methyl5-(1-methylethyl) (Carvacrol) from Streptomyces griseus has cytotoxic effect on peroxidant activity, antifungal activity against Penicillium glabrum, $P$. capisci, R. solani, F. moniiliforme, S. sclerotiorum, and Cladosporium herbarum (Danaei et al. 2014). Cyclohexanol, benzaldehyde and naphthalene possessed antimicrobial effects (Danaei et al. 2014). 
Table 2. List of antimicrobial compounds of different Streptomyces screened against various plant pathogens

\begin{tabular}{|c|c|c|c|c|}
\hline Metabolite & Structure & Organism & Disease & Reference \\
\hline Natamycin & & S. lydicus strain A01 & $\begin{array}{l}\text { Fusarium oxysporum, } \\
\text { Botrytis cinerea, Monilinia } \\
\text { laxa }\end{array}$ & Lu et al. (2008) \\
\hline Antimycin A17 & & Streptomyces sp. GAAS7310 & $\begin{array}{l}\text { Curvularia lunata, } \\
\text { Rhizopus nigricans, and } \\
\text { Colletotrichum nigrum }\end{array}$ & Chen et al. (2005) \\
\hline Oligomycins A and C & & S. diastaticus & $\begin{array}{l}\text { Aspergillus niger, Alternaria } \\
\text { alternata, B. cinerea, and } P \text {. } \\
\text { capsici }\end{array}$ & Yang et al. (2010) \\
\hline Rapamycin & & S. diastaticus & $\begin{array}{l}\text { Aspergillus niger, Alternaria } \\
\text { alternata, Botrytis cinerea } \\
\text { and Phytophthora capsici }\end{array}$ & Yang et al. (2010) \\
\hline Propanoic acid & & S. lavendulocolor VHB-9 & M. grisea & Bindu et al. (2017) \\
\hline Avermectins & & S. avermitilis & Fusarium oxysporum & $\begin{array}{l}\text { Cheng et al. } \\
\text { (2018) }\end{array}$ \\
\hline Lucensomycin & & S. plumbeus strain CA5 & B. cinerea & Kim et al. (2020) \\
\hline
\end{tabular}


VOCs secreted by S. alboflavus TD-1 possess activity against Aspergillus ochraceus (Yang et al. 2018). Inhibition of Sclerotinia sclerotiorum mycelial growth and spore germination was achieved by the VOCs Cyclohexanol, decanol, 2-ethyl-1-hexanol, nonanol, benzothiazole and dimethyl trisulfide (Fernando et al. 2005).

\section{Against bacterial pathogens}

S. termitum ATC-2 produced an antimicrobial compound aloesaponarin II which exhibited antimicrobial activity against rice bacterial blight disease (Donghua et al. 2013). Similarly, Mingma et al. (2014) reported the inhibition of Xanthomonas campestris pv. glycines causing bacterial pustule on soybean by Streptomyces sp. strain RM 365 and Pectobacterium carotovorum and P. atrosepticum causing soft rot of potato was reduced up to 90 per cent by Streptomyces sp. strain OE7 (Baz et al. 2012).

\section{(iii) As a root colonizer and defense activator}

The rhizosphere is a repository for all chemical and biological interactions in the soil matrix, which contains a diversified groups of bacteria including beneficial and harmful. (Raaijmakers et al. 2009; Compant et al. 2010; Glick 2012). One of the essentialities of biocontrol agents is to colonize the roots effectively in which higher colonization leads to higher efficacy against plant pathogens. Deleterious microbes compete for nutrients whereas beneficial microbes mobilize the plant nutrients and protect from plant diseases (Solanki et al. 2013). A superior model of actinomycetes for rhizosphere colonization is S. griseoviridis isolated from sphagnum peat (Tahvonen 1982) used against cucumber root rot, damping-off in crucifers and carnation fusarial wilt. Cheng et al. (2018) reported the colonization of Sclerotinia sclerotiorum in oilseed rape by S. felleus YJ1and enhanced activities of Peroxidase (PO), polyphenol oxidase (PPO), superoxide dismutase (SOD) associated with plant disease resistance (Kim and Hwang 2007). POD aids in lignin formation by enhancing thickness of cell wall, PPO oxidizes phenols to quinone, PAL enhance the production of phenolic compounds lignans and phytoalexin which promotes systemic resistance in plant (Wang et al. 2013).

\section{(iv) Plant growth promotion}

As like other PGPRs, Streptomyces also has the capability to promote plant growth and increase the crop yield through acquiring nutrients or by secretion of growth regulators. The plant biomass got enhanced by the inoculation of Streptomyces strains into plants like tomato wheat, sorghum and rice (Palaniyandi et al. 2011). Plant growth promotion was achieved through some mechanisms including phosphate solubilization $\mathrm{N}_{2}$ fixation, ACCdeaminase production, sulphur oxidation and acquisition of iron for plant growth promotion (Jaemsaeng et al. 2018). Tomato plants inoculated with 1-aminocyclopropane-1-carboxylate deaminase (ACCD) producing endophytic Streptomyces sp. GMKU 336 showed resistance during waterlogged conditions (Jaemsaeng et al. 2018). Five isolates including Streptomyces sp., S. tsusimaensis, S. caviscabies, S. setonii and S. africanus were highly effective against chick pea wilt caused by $F$. oxysporum f. sp. ciceri besides promoting plant growth ability on Sorghum and rice crops (Gopalakrishnan et al. 2013).

\section{Phosphate solubilization}

Though phosphorus plays an important role in plant growth, its availability is limited in soil and hence supplemented with chemical fertilizers. Due to its hasty immobilization, majorily they are leached off and proportionately a little is available for the plants (Shigaki et al. 2006). Being a potential root colonizer and an agent for altering insoluble phosphorus in to available (Hamdali et al. 2008) through production of solubilizing acids like propionic acid, lactic acid, citric acid, gluconic acid, malic acid, succinic and oxalic acids, the filamentous Streptomycetes sp. are given with due attention and hence, the $S$. griseus and other Streptomyces sp. are potentially used as a phosphate solubilizer in phosphorus deficient soils (Jog et al. 2014).

\section{Siderophore production}

Proliferation of pathogenic micro-organisms is prevented by the siderophore producing rhizobacteria and which mostly belong to Streptomyces Serratia Pseudomonas Rhizobium and Bradyrhizobium genera (Kuffner et al. 2008). Streptomyces spp. produce hydroxymate type siderophore that protects the plants against pathogens (Khamna et al. 2009). Streptomyces rochei IDWR 19 which produces a 
hydroxymate siderophore at the rate of $34.17 \mathrm{mg} / \mathrm{l}$ (Jog et al. 2014).

\section{IAA production}

Plant growth promotion is also due to production of growth regulators. The principal form of auxin is IAA which performs various functions like cell differentiation, elongation, division, development of embryo and fruits, vascular tissue differentiation, organogenesis, root patterning, apical hook formation and apical dominance (Khamna et al. 2009). Streptomyces species like S. rochei, S. rimosus and S. olivaceoviridis from the tomato rhizosphere, have the potential to produce IAA and improve plant growth by increased seed germination, root elongation and root dry weight (El-Tarabily and Khaled 2008).

Streptomyces has been found to produce natural auxin (IAA) ( El-Tarabily and Khaled, 2008; Khamna et al. 2009). Plant growth has also been observed to be aided by gibberellins and cytokinin-like compounds generated by S. rimosus, S. olivaceoviridis, and S. rochei (Palaniyandi et al. 2011). Auxins also supports in stimulation of root hairs, lateral root formation and sugar secretion which in turn plays an important role in early microbial root colonization. Streptomyces sp. which produces IAA and siderophore also increases the availability of trace elements like zinc, iron besides stimulating the growth and elongation of plant roots (Cakmakci et al. 2006).

\section{Commercially available strains}

Ten species of Streptomyces have been registered as commercial goods (Vurukonda et al. 2018), while a few more are in the early stages of commercial formulation development. The actinobacterial formulations Mycostop and Actinovate have been commercially exploited for a long time. Owing to the presence of antifungal antibiotic, aromatic heptaenepolyene, Mycostop (S. griseoviridis K61 strain isolated from sphagnum peat) and registered in Canada, the European Union, and the United States for use against seed and soil borne fungal diseases. Similarly, the Actinovate made from the S. lydicus WYEC 108 strain suppresses Pythium ultimum and Rhizoctonia solani growth besides promoting plant growth. Actinovate have also been used to prevent Fusarium, Phytophthora, Verticillium, and foliar diseases such powdery and downy mildew (Vurukonda et al. 2018). In United States and Ukraine, Blasticidin-S against rice blast and Kasugamycin against Phytophthora led root rot and leaf spot in various crops have been registered, respectively (Aggarwal et al. 2016). The wettable Streptomyces sp. Di-944 formulation prevents the damping off disease of tomatoes caused by Rhizoctonia solani (Sabaratnam and Traquair 2002).

\section{Advantages and disadvantages of Streptomyces bio-inoculant}

\section{Advantages}

The metabolites from actinomycetes are naturally occurring and gaining importance in plant disease management. Considering its frequency, dominance and potential as agro chemical it could be marketed commercially (Solanki et al. 2016).

- Less harmful and eco friendly;

- Targets the specific organism and decomposes quickly;

- Supplies micronutrients and balances the soil nutrient cycle;

- Regulates plant metabolism against diseases;

- Efficient colonizer of roots and supports colonization of mycorrhiza.

\section{Disadvantages}

- Storage is a major problem;

- Success rate is low;

- Compared to other bacterial inoculants, proliferation rate is slow.

\section{CONCLUSION}

Considering the potentiality and various mechanism employed by Streptomyces sp. it could be used as a bio inoculant for disease management. The constraint is that all the strains performing better under in vitro condition, cannot perform in the same manner under in vivo condition. Hence efficient technique must be developed to identify the strain performing well under both conditions.

\section{Future perspectives}

Microorganisms generally play a vivacious role in plant disease management. Among those, 
Streptomyces have been focused by researchers and commercial products are made with its metabolites which symbolises its use as a bio inoculant for disease control. To date only active Streptomyces sp. have been isolated from rhizosphere soil. Research should be focused on identifying novel rare Streptomyces sp. from unexplored environments which will have immense potential of producing antibiotics. Research on methods to elute the identified antimicrobial compounds should be studied to make it available commercially. In addition, optimization of suitable carrier, avoiding deleterious metabolites and genetic engineering of the effective strain will be helpful in making commercial product for agriculture purpose.

\section{REFERENCES}

Adegboye, M.F., and Babalola, O.O. 2012. Taxonomy and ecology of antibiotic producing actinomycetes. African J. of Agricul. Res., 7(15): 2255-2261.

Adhilakshmi, M., Latha, P., Paranidharan, V., Balachandar, D., Ganesamurthy, K., and Velazhahan, R. 2014. Biological control of stem rot of groundnut (Arachis hypogaea L.) caused by Sclerotium rolfsii Sacc. with actinomycetes. Archives of Phytopathol. and Pl. Prot., 47(3): 298-311.

Aggarwal, N., Thind, S. K., and Sharma, S. 2016. Role of secondary metabolites of actinomycetes in crop protection. In Plant Growth Promoting Actinobacteria. Subramaniam, Gopalakrishnan, Arumugam, Sathya, Rajendran, Vijayabharathi (Eds.) Springer, Singapore. pp. 99-121

Anandan, R., Dharumadurai, D. and Manogaran, G. P. 2016. An introduction to actinobacteria. In Actinobacteria-Basics and Biotechnological Applications. Dhanasekaran, D. and Jiang, Y. (Eds.) Intechopen, p. 3-37.

Anwar, S., Ali, B. and Sajid, I. 2016. Screening of rhizospheric actinomycetes for various in-vitro and in-vivo plant growth promoting (PGP) traits and for agroactive compounds. Front. in Microbiol., 7: 1334.

Ashokvardhan, T., Rajithasri, A., Prathyusha, P. and Satyaprasad, K. 2014. Actinomycetes from Capsicum annuum L. rhizosphere soil have the biocontrol potential against pathogenic fungi. Int. J. Curr. Microbiol. Appl. Sci., 3: 894903.

Atta, H.M. 2015. Biochemical studies on antibiotic production from Streptomyces sp.: Taxonomy, fermentation, isolation and biological properties. J. of Saudi Chem. Soc., 19(1): 12-22.

Baz, M., Lahbabi, D., Samri, S., Val, F., Hamelin, G., Madore, I. and Barakate, M. 2012. Control of potato soft rot caused by Pectobacterium carotovorum and Pectobacterium atrosepticum by Moroccan actinobacteria isolates. World J. of Microbiol. and Biotechnol., 28(1): 303-311.
Berdy, J. 2005. Bioactive microbial metabolites, a personal view. J. of Antibiotics, 58: 126

Bharathi, R., Vivekananthan, R., Harish, S., Ramanathan, A. and Samiyappan, R. 2004. Rhizobacteria based bioformulations for the management of fruit rot infection in chillies. Crop Protn., 23: 835-843.

Bhardwaj, A. and Agrawal, P. 2014. A review fungal endophytes: as a store house of bioactive compound. World J. of Pharmacueticals, 3(9): 228 - 237.

Bindu, B.S.S.N.H., Muvva, H.V., Munaganti, R., Naragani, K., Konda, S. and Dorigondla, K. 2017. Production of antimicrobial metabolites by Streptomyces lavendulocolor VHB-9 isolated from granite mines. Brazilian Archives of Biol. and Technol., 60: 1 - 13.

Bouizgarne, L.B., Lanoot, B., Loqman, S., Sproer, C., Klenk, H.P., Swings, J. and Ouhdouch, Y. 2009. Streptomyces marokkonensis sp. nov., isolated from rhizosphere soil of Argania spinosa. Intl. J. of Systematic and Evolutionary Microbiol., 59: 2857-2863.

Cakmakci, R., Donmez, F., Aydın, A. and Sahin, F. 2006. Growth promotion of plants by plant growth-promoting rhizobacteria under greenhouse and two different field soil conditions. Soil Biol. and Biochem., 38: 1482-1489.

Cao, L., Qiu, Z., You, J., Tan, H. and Zhou, S. 2004. Isolation and characterization of endophytic Streptomyces strains from surface-sterilized tomato (Lycopersicon esculentum) roots. Letters in Applied Microbiol., 39(5): 425-430.

Chaiharn, M., Theantana, T. and Pathom-Aree, W. 2020. Evaluation of biocontrol activities of Streptomyces spp. against rice blast disease fungi. Pathogens, 9(2): 126.

Chen, C., Belanger, R., Benhamou, N. and Paulitz, T. 2005. Defense enzymes induced in cucumber roots by treatment with plant growth-promoting rhizobacteria (PGPR) and Pythium aphanidermatum. Physiol. and mol. Pl. Pathol., 56(1): 13-23.

Chen, Y., Zhou, D., Qi, D., Gao, Z., Xie, J., and Luo, Y. 2018. Growth promotion and disease suppression ability of a Streptomyces sp. CB-75 from banana rhizosphere soil. Front. in Microbiol., 8: 2704.

Cheng, G., Huang, Y., Yang, H. and Liu, F. 2018. Streptomyces felleus YJ1: Potential biocontrol agents against the sclerotinia stem rot (Sclerotinia sclerotiorum) of oilseed rape. J. of Agricul. Sci., 6(4): 91.

Compant, S., Clement, C. and Sessitsch, A. 2010. Plant growth-promoting bacteria in the rhizo-and endosphere of plants: their role, colonization, mechanisms involved and prospects for utilization. Soil Biol. and Biochem., 42(5): 669-678.

Danaei, M., Baghizadeh, A., Pourseyedi, S., Amini, J. and Yaghoobi, M.M. 2014. Biological control of plant fungal diseases using volatile substances of Streptomyces griseus. European J. of Experil. Biol., 4(1): 334-339.

Devi, S.S. and Rao, K.B. 2017. Exploration of antimicrobial compounds from Streptomyces S9 against a phytopathogen, Corynespora cassiicola (Berk \& Curtis). J. of Biopesticides, 10(1): $1-9$. 
Donghua, J., Qinying, L., Yiming, S. and Hao, J. 2013. Antimicrobial compound from a novel Streptomyces termitum strain ATC-2 against Xanthomonas oryzae pv. oryzae. Res. J. of Biotechnol., 8: 66-70.

Elamvazhuthi, P. and Subramanian, M. 2013. Antagonistic activity of actinomycetes from Jeypore paddy soils against selective phytopathogenic fungi. J. of Modern Biotechnol., 2: 66-72.

El-Tarabily and Khaled, A. 2008. Promotion of tomato (Lycopersicon esculentum Mill.) plant growth by rhizosphere competent 1-aminocyclopropane-1-carboxylic acid deaminase-producing streptomycete actinomycetes. Plant and Soil, 308(1-2): 161-174.

El-Tarabily, K. and Sivasithamparam, K. 2006. Nonstreptomycete actinomycetes as biocontrol agents of soil-borne fungal plant pathogens and as plant growth promoters. Soil Biol. and Biochem., 38(7): 1505-1520.

Fernando, W.D., Ramarathnam, R., Krishnamoorthy, A.S. and Savchuk, S.C. 2005. Identification and use of potential bacterial organic antifungal volatiles in biocontrol. Soil Biol. and Biochem., 37(5): 955-964.

Glick, B.R. 2012. Plant growth-promoting bacteria: mechanisms and applications. Scientifica, 963401: 1 - 15

Goodfellow, M. and Williams, S.T. 1983. Ecology of actinomycetes. Annl. Rev. of Microb., 37(1): 189-216.

Gopalakrishnan, S., Pande, S., Sharma, M., Humayun, P., Kiran, B.K., Sandeep, D. and Rupela, O. 2011. Evaluation of actinomycete isolates obtained from herbal vermicompost for the biological control of Fusarium wilt of chickpea. Crop Protn., 30(8): 1070-1078.

Gopalakrishnan, S., Vadlamudi, S., Apparla, S., Bandikinda, P., Vijayabharathi, R., Bhimineni, R.K. and Rupela, O. 2013. Evaluation of Streptomyces spp. for their plant growthpromotion traits in rice. Can. J. Microbiol., 59: 534-539.

Goudjal, Y., Toumatia, O., Yekkour, A., Sabaou, N., Mathieu, F. and Zitouni, A. 2014. Biocontrol of Rhizoctonia solani damping-off and promotion of tomato plant growth by endophytic actinomycetes isolated from native plants of Algerian Sahara. Microb. Res., 169(1): 59-65.

Gowdar, S.B., Deepa, H. and Amaresh, Y.S. 2018. A brief review on biocontrol potential and PGPR traits of Streptomyces sp. for the management of plant diseases. J. of Pharmacol. and Phytochem., 7(5): 03-07.

Haggag, W.M. and Mohamed, H.A.A. 2007. Biotechnological aspects of microorganisms used in plant biological control. American-Eurasian J. of Sustainable Agricul., 1:7-12.

Hamdali, H., Hafidi, M., Virolle, M. J. and Ouhdouch, Y. 2008. Rock phosphate-solubilizing Actinomycetes: screening for plant growth-promoting activities. World J. of Microb. and Biotech., 24(11): 2565-2575.

Harada, S. and Kishi, T. 1978. Isolation and characterization of mildiomycin, a new nucleoside antibiotic. The J. Antibiotics, 31(6): 519 - 524.

Harikrishnan, H., Shanmugaiah, V. and Balasubramanian, N. 2014. Optimization for production of Indole acetic acid (IAA) by plant growth promoting Streptomyces sp
VSMGT1014 isolated from rice rhizosphere. Int. J. of Current Microbiol. and Appl. Sci., 3(8): 158-171.

Hassan, A.A., El-Barawy, A.M. and El Mokhtar, M.N. 2011. Evaluation of biological compounds of Streptomyces species for control of some fungal diseases. J. of American Sci., 7(4): 752-760.

Intra, B., Mungsuntisuk, I., Nihira, T., Igarashi, Y. and Panbangred, W. 2011. Identification of actinomycetes from plant rhizospheric soils with inhibitory activity against Colletotrichum spp., the causative agent of anthracnose disease. BMC Res. Notes, 4(1): 1-9.

Isono, K., Nagatsu, J., Kawashima, Y. and Suzuki, S. 1965. Studies on polyoxins, antifungal antibiotics. Part I. Isolation and characterization of polyoxins A and B. Agric. Biol. Chem., 29: 848-854.

Jaemsaeng, R., Jantasuriyarat, C. and Thamchaipenet, A. 2018. Molecular interaction of 1-aminocyclopropane-1carboxylate deaminase (ACCD)-producing endophytic Streptomyces sp. GMKU 336 towards salt-stress resistance of Oryza sativa L. cv. KDML105. Scientific Rep., 8(1): 1-15.

Jog, R., Pandya, M., Nareshkumar, G. and Rajkumar, S. 2014. Mechanism of phosphate solubilization and antifungal activity of Streptomyces spp. isolated from wheat roots and rhizosphere and their application in improving plant growth. Microbiol., 160(4): 778-788.

Joo, G.J. 2005. Production of an anti-fungal substance for biological control of Phytophthora capsici causing phytophthora blight in red-peppers by Streptomyces halstedii. Biotechnol. Letters, 27(3): 201-205.

Junaid, J.M., Dar, N.A., Bhat, T.A., Bhat, A.H. and Bhat, M.A. 2013. Commercial biocontrol agents and their mechanism of action in the management of plant pathogens. Internl. J. of Modern Plant and Animal Sci., 1(2): 39-57.

Kalyani, A., Sravani, K.R. and Annapuma, J. 2012. Isolation and characterization of antibiotic poducing actinomycetes from marine soil samples. Int. J. Curr. Pharmaceutical Res., pp. 110-112.

Kanini, G.S., Katsifas, E.A., Savvides, A.L. and Karagouni, A.D. 2013. Streptomyces rochei ACTA1551, an indigenous Greek isolate studied as a potential biocontrol agent against Fusarium oxysporum f. sp. lycopersici. BioMed Res. Int., article ID 387230: 1 -10.

Khamna, S., Yokota, A., Peberdy, J. and Lumyong, S. 2009. Antifungal activity of Streptomyces spp. isolated from rhizosphere of Thai medicinal plants. Int. J. Integrative Biol., 6(3): 143-147.

Kim, B.S. and Hwang, B.K. 2007. Microbial fungicides in the control of plant diseases. J. of Phytopathol., 155(11-12): 641-653.

Kim, B.S., Moon, S.S. and Hwang, B.K. 2011. Isolation, identification, and antifungal activity of a macrolide antibiotic, oligomycin A, produced by Streptomyces libani. Can. J. of Bot., 77(6): 850-858

Kim, J.D., Kang, J. E. and Kim, B. S. 2020. Postharvest disease control efficacy of the polyene macrolide lucensomycin produced by Streptomyces plumbeus strain CA5 against 
gray mold on grapes. Postharvest Biol. and Technol., 162: $111-115$.

Kuffner, M., Puschenreiter, M., Wieshammer, G., Gorfer, M. and Sessitsch, A. 2008. Rhizosphere bacteria affect growth and metal uptake of heavy metal accumulating willows. Plant and Soil, 304(1-2): 35-44.

Law, J.W., Ser, H.L., Khan, T. M., Chuah, L.H., Pusparajah, P., Chan, K.G. et al. 2017. The potential of Streptomyces as biocontrol agents against the rice blast fungus, Magnaporthe oryzae (Pyricularia oryzae). Front. Microbiol., 8: 3.

Lee, J.P., Lee, S.W., Kim, C.S., Son, J.H., Jung, S.J. and Moon, B.J. 2006. Evaluation of formulations of Bacillus licheniformis for the biological control of tomato gray mold caused by Botrytis cinerea. Biological Contl., 37: 329-337.

Liang, J.F., Xue, Q.H., Niu, X.L. and Li, Z.B. 2005 Root colonization and effects of seven strains of actinomycetes on leaf PAL and PPO activities of capsicum. Acta Bot. Boreal-Occident Sin., 25: 2118-2123.

Liu, Y., Shi, J., Feng, Y., Yang, X., Li, X. and Shen, Q. 2013. Tobacco bacterial wilt can be biologically controlled by the application of antagonistic strains in combination with organic fertilizer. Biol. and Fertility of Soils, 49(4): 447-464.

Lu, C.G., Liu, W.C., Qiu, J.Y., Wang, H.M., Liu, T. and Liu, D.W. 2008. Identification of an antifungal metabolite produced by a potential biocontrol actinomyces strain A01. Brazilian J. of Microb., 39(4): 701-707.

Lyu, A., Liu, H., Che, H., Yang, L., Zhang, J., Wu, M. and Li, G. 2017. Reveromycins A and B from Streptomyces sp. 3-10: antifungal activity against plant pathogenic fungi in vitro and in a strawberry food model system. Front. in Microb., 8: 550.

Madigan, M.T., Martinko, J.M., Stahl, D.A. and Clark, D.P. 2012. Brock Biology of Microorganisms $13^{\text {th }}$ Edition. Pearson Education, Inc.,CA., pp. 1043.

Malviya, M. K., Pandey, A., Trivedi, P., Gupta, G. and Kumar, B. 2009. Chitinolytic activity of cold tolerant antagonistic species of Streptomyces isolated from glacial sites of Indian Himalaya. Current Microb., 59(5): 502-508.

Manasa, M., Yashoda, K., Pallavi, S., Vivek, M.N., Onkarappa, R. and Kekuda, T.R.P. 2013. Biocontrol potential of Streptomyces species against Fusarium oxysporum f. sp. zingiberi (causal agent of rhizome rot of ginger). J. of Adv. Sci. and Res., 4: 1-3.

Masand, M., Sivakala, K., Menghani, E., Thinesh, T., Anandham, R., Sharma, G., Sivakumar, N., Jebakumar, S. and Jose, P. 2018. Biosynthetic potential of bioactive Streptomycetes isolated from arid region of the Thar desert, Rajasthan (India). Front. in Micro., 9: 687.

Mingma, R., Pathom-aree, W., Trakulnaleamsai, S., Thamchaipenet, A. and Duangmal, K. 2014. Isolation of rhizospheric and roots endophytic actinomycetes from Leguminosae plant and their activities to inhibit soybean pathogen, Xanthomonas campestris pv. glycine. World J. of Microb. and Biotech., 30(1): 271-280.
Morales-Gonzalez, M., Martinez, B., Ramirez-Rodriguez, L., Gómez, J. and Diaz, L. 2018. Optimization of L-asparaginase activity of Actinobacteria isolated from Guaviare river sediments in Colombia. Tropical J. of Pharmaceutical Res., 17(11): 2199-2206.

Nguyen, X.H., Naing, K.W., Lee, Y.S., Kim, Y.H., Moon, J.H. and Kim, K.Y. 2015. Antagonism of antifungal metabolites from Streptomyces griseus H7602 against Phytophthora capsici. J. of Basic Microb., 55(1): 45-53.

Nimaichand, S., Tamrihao, K., Yang, L.L., Zhu, W.Y., Zhang, Y.G., Li, L. and Li, W.J. 2013. Streptomyces hundungensis sp. nov., a novel actinomycete with antifungal activity and plant growth promoting traits. The J. of Antibiotics, 66(4): 205-209.

Palaniyandi, S. A., Yang, S.H., Cheng, J.H., Meng, L. and Suh, J.W. 2011. Biological control of anthracnose (Colletotrichum gloeosporioides) in yam by Streptomyces sp. MJM5763. J. of Appl. Microb., 111(2): 443-455.

Patil, H.J., Srivastava, A.K., Singh, D.P., Chaudhari, B.L. and Arora, D.K. 2011. Actinomycetes mediated biochemical responses in tomato (Solanum lycopersicum) enhances bioprotection against Rhizoctonia solani. Crop Protn., 30(10): 1269-1273.

Pattanapipitpaisal, P. and Kamlandharn, R. 2012. Screening of chitinolytic actinomycetes for biological control of Sclerotium rolfsii stem rot disease of chilli. Songklanakarin J. of Sci. E Technol., 34(4): 387-393.

Poomthongdee, N., Duangmal, K. and Pathom-aree, W. 2015. Acidophilic actinomycetes from rhizosphere soil: diversity and properties beneficial to plants. The J. of Antibiotics, 68(2): 106-114.

Prapagdee, B., Kuekulvong, C. and Mongkolsuk, S. 2008. Antifungal potential of extracellular metabolites produced by Streptomyces hygroscopicus against phytopathogenic fungi. Internl. J. of Biol. Sci., 4(5): 330.

Raaijmakers, J.M., Paulitz, T.C., Steinberg, C., Alabouvette, C. and Moënne-Loccoz, Y. 2009. The rhizosphere: a playground and battlefield for soilborne pathogens and beneficial microorganisms. Plant and Soil, 321(1):341-361.

Rey, T. and Dumas, B. 2017. Plenty is no plague: Streptomyces symbiosis with crops. Trends in Pl. Sci., 22(1): 30-37.

Sabaratnam, S. and Traquair, J.A. 2002. Formulation of a Streptomyces biocontrol agent for the suppression of Rhizoctonia damping-off in tomato transplants. Biol. Contrl., 23(3): 245-253.

Sangmanee, P., Bhromsiri, A. and Akarapisan, A. 2009. The potential of endophytic actinomycetes, (Streptomyces sp.) for the biocontrol of powdery mildew disease in sweet pea (Pisum satioum). Asian J. of Food and Agricul. Indus., 93: e8.

Savary, S., Ficke, A., Aubertot, J.N. and Hollier, C. 2012. Crop losses due to diseases and their implications for global food production losses and food security. Food Security 4(4): 519- 537.

Saxena, S. 2014. Microbial metabolites for development of ecofriendly agrochemicals. Allelopathy J., 33(1): 1-24. 
Sharma, D., Mayilraj, S. and Manhas, R. 2014. Streptomyces amritsarensis sp. nov., exhibiting broad-spectrum antimicrobial activity. Antonie Van Leeuwenhoek, 105(5): 943-949.

Shigaki, F., Sharpley, A. and Prochnow, L. 2006. Animal-based agriculture, phosphorus management and water quality in Brazil: Options for the future. Scientia Agricola, 63(2): 194-209.

Siupka, P., Hansen, F.T., Schier, A., Rocco, S., Sorensen, T. and Piotrowska-Seget, Z. 2021. Antifungal activity and biosynthetic potential of new Streptomyces sp. MW-W60010 strain isolated from coal mine water. Int. J. of Mol. Sci., 22(14): 7441.

Solanki, M.K., Malviya, M.K. and Wang, Z. 2016. Actinomycetes bio-inoculants: A modern prospectus for plant disease management. In Plant growth promoting actinobacteria. Subramaniam, Gopalakrishnan, Arumugam, Sathya, Rajendran, Vijayabharathi (Eds.). Springer, Singapore, pp. 63-81.

Sonia, M.T., Jedidi, N. and Abdennaceur, H. 2011. Studies on the ecology of actinomycetes in an agricultural soil amended with organic residues: I. identification of the dominant groups of actinomycetales. World J. Microb. Biotech., 27: 2239-2249.

Srividya, S., Thapa, A., Bhat, D.V., Golmei, K. and Nilanjan, D. 2012. Streptomyces sp. 9p as effective biocontrol against chili soilborne fungal phytopathogens. European J. of Experl. Biol., 2: 163-173.

Tahvonen, R. 1982. The suppressiveness of Finnish light coloured Sphagnum peat. Agricul. and Food Sci., 54(5): 345-356.

Trejo-Estrada, S.R., Paszczynski, A. and Crawford, D.L. 1998. Antibiotics and enzymes produced by the biocontrol agent Streptomyces violaceusniger YCED-9. J. Ind. Microb. Biotech., 21: 81-90.

Vurukonda, S.S.K.P., Giovanardi, D. and Stefani, E. 2018. Plant growth promoting and biocontrol activity of Streptomyces spp. as endophytes. Internl. J. of Mol. Sci., 19(4): 952.

Wan, M., Li, G., Zhang, J., Jiang, D. and Huang, H.C. 2008. Effect of volatile substances of Streptomyces platensis F-1 on control of plant fungal diseases. Biol. Contrl., 46(3): 552-559.

Wang, C., Wang, Z., Qiao, X., Li, Z., Li, F., Chen, M., Wang, Y., Huang, Y. and Cui, H. 2013. Antifungal activity of volatile organic compounds from Streptomyces alboflavus TD-1. FEMS Microb. Letters, 341(1): 45-51.
Whitman, W., Goodfellow, M., Kampfer, P., Busse, H.J., Trujillo, M., Ludwig, W., Suzuki, K.I. and Parte, A. 2012. Bergey's manual of systematic bacteriology, vol 5: The Actinobacteria. Springer-Verlag New York.

Wildermuth, H. 1970. Development and organization of the aerial mycelium in Streptomyces coelicolor. J. of Gen. and Appl. Microb., 60: 43-50.

Wildermuth, H. and Hopwood, D.A. 1970. Septation during sporulation in Streptomyces coelicolor. J. Gen. Micro., 60: 51-59.

Xiong, Z.Q., Tu, X.R., Wei, S.J., Huang, L., Li, X.H., Lu, H. and Tu, G.Q. 2013. The mechanism of antifungal action of a new polyene macrolide antibiotic antifungalmycin 702 from Streptomyces padanus JAU4234 on the rice sheath blight pathogen Rhizoctonia solani. PloS One, 8(8): e73884.

Yandigeri, M.S., Malviya, N., Solanki, M.K., Shrivastava, P. and Sivakumar, G. 2015. Chitinolytic Streptomyces vinaceusdrappus S5MW2 isolated from Chilika lake, India enhances plant growth and biocontrol efficacy through chitin supplementation against Rhizoctonia solani. World J. of Microb. and Biotech., 31(8): 1217-1225.

Yang, M., Huang, C., Xue, Y., Li, S., Lu, L. and Wang, C. 2018. Biofumigation with volatile organic compounds from Streptomyces alboflavus TD-1 and pure chemicals to control Aspergillus ochraceus. Annals of Appl. Biol., 173(3): 313-322.

Yang, P.W., Li, M.G., Zhao, J.Y., Zhu, M.Z., Shang, H., Li, J.R. and Wen, M.L. 2010. Oligomycins A and C, major secondary metabolites isolated from the newly isolated strain Streptomyces Diastaticus. Folia Microbiologica, 55(1): 10-16.

Zhang, Q., Yong, D., Zhang, Y., Shi, X., Li, B., Li, G. and Wang, C. 2016. Streptomyces rochei A-1 induces resistance and defense-related responses against Botryosphaeria dothidea in apple fruit during storage. Postharvest Biol. and Technol., 115: 30-37.

Zhao, S., Du, C.M. and Tian, C.Y. 2012. Suppression of Fusarium oxysporum and induced resistance of plants involved in the biocontrol of Cucumber Fusarium Wilt by Streptomyces bikiniensis HD-087. World J. of Microb. and Biotech., 28(9): 2919-2927. 
